\title{
CARRYING CAPACITY ASSESSMENT AND SUSTAINABLE TOURISM MANAGEMENT IN AGRA CITY, UTTAR PRADESH (INDIA)
}

\author{
Vishwa RAJ SHARMA* \\ University of Delhi, Shaheed Bhagat Singh College, Sheikh Sarai Phase-II, \\ New Delhi-110017, India, e-mail: vrsharma2002@gmail.com \\ Kamal BISHT \\ University of Delhi, Shaheed Bhagat Singh College, Sheikh Sarai Phase-II, \\ New Delhi-110017, India, e-mail: kamal_bisht24@hotmail.com
}

\begin{abstract}
Citation: Raj Sharma, V., \& Bisht, K. (2019). CARRYING CAPACITY ASSESSMENT AND SUSTAINABLE TOURISM MANAGEMENT IN AGRA CITY, UTTAR PRADESH (INDIA). GeoJournal of Tourism and Geosites, 25(2), 399-407. https://doi.org/10.30892/gtg.25211-369

Abstract: The issues of tourism sustainability and management have become main concern for tourism industry of Agra city. Presently, tourism becomes global activity and impact worldwide, therefore it is a requirement for sustainable tourism management and it is possible through calculating carrying capacity. This study explores present tourism status of Agra city and its problems. The main aim of the study is to disclose carrying capacity of Agra city and prepare the sustainable development plan for tourism sector. The uniqueness and assessment of this study is based on empirical research with the help of a field survey. Evaluating Carrying capacity of Agra by DPSIR Model (Drivers, Pressures, State, Impacts, and Responses) which is develop by the European Environmental Agency, which highlights critical links and relationships between human activities, pressures on the environment and impacts on ecosystems (European Environment Agency, 1999). Calculating, physical, environmental and social carrying capacity of Agra exposes the pressure on city and future scope of tourism development. The poor carrying capacity of Agra, lead to poor satisfaction level of visitor at Agra city that damage its status around the world. The output of study support forthcoming researches in the area of managing sustainable tourism development.
\end{abstract}

Keywords: Tourism Carrying Capacity, Sustainable Tourism Management, DPSIR Model, Combined Satisfaction Index

\section{INTRODUCTION}

Tourism is one of the most wide spread activity in the world may be more than ever and its impact become more visible on world landscape in term of positive and negative.

\footnotetext{
* Corresponding author
} 
Tourism activities cause change of Physical, Environmental and cultural properties of any tourist destination. It is sustainable tourism with a primary focus on experiencing the earth's geological features in a way that fosters environmental and cultural understanding, appreciation and conservation, and is locally beneficial (Dowling \& Newsome, 2006).

Therefore, the aim of this study is to explore how sustainable tourism development of Agra can achieved and managed through the concept of carrying capacity. World Tourism Organization has defined Tourism Carrying Capacity as "the maximum number of person which could visit a location within a given period, such that local environmental, physical, economic and socio-cultural characteristics are not compromised and without reducing tourist satisfaction" (Castellani et al., 2007) defines the types of carrying capacity such as Physical, Economic and Social. a) The physical carrying capacity is a threshold limit, beyond which natural and cultural heritage destination is destroyed by tourism. b) Economic carrying capacity is the threshold limit over which tourism growth becomes economically intolerable due to the presence of a great number of tourists makes the destination uncomfortable and causes a reduction in tourism demand. Another reason behind the tourist destination turns into economically unsuitable when tourism interferes with other economic activities obstructing their development. c) The social carrying capacity is the threshold value beyond which the social profile of the host community badly influenced and damaged by tourism activities. This situation creates conflict between tourists and the local host community. A better understanding of the earth with reference to its geological attraction is the goal of geotourism which arises from the motivation of enjoying unique features amidst of landscape (Adriansyah et al., 2015). The unprecedented growth of tourism raises a number of concerns over the environmental and cultural integrity of tourist destination that led to a re-examination of tourism development in the light of the increasingly popular concept of sustainable development, (Drost, 1996). The unplanned and haphazard growth of tourism industry is resulting in major environmental problems.

This results in ruining of cultural heritage, vanishing of historical depictions and degeneration of natural beauties over many parts of the globe. It is a great loss for human society. To protect physical as well as socio-cultural environment of tourist sites it is necessary to follow the principles of sustainability with increasing growth of this industry (Nimesh, 2013). The 1982 joint declaration of the World Tourism Organization (WTO) and the United Nations Environment Program (UNEP) develop the goal of sustainable tourism: the protection, enhancement and improvement of the various components of man's environments are among the fundamental conditions for the harmonious development of tourism. Similarly, rational management of tourism may contribute to a large extent to protecting and developing the physical environment and the cultural heritage, as well as improving the quality of life. Geotourism is emerging as a new global phenomenon (Dowling, 2008a). In September 2015 post Millennium Development Goals period, the United Nations Sustainable Development Summit was held and here the world leaders adopted 2030 Agenda for Sustainable Development, that includes a set of 17 Sustainable Development Goals (SDGs) to end poverty, fight inequality and injustice, and tackle climate change by 2030. The main focus is early intervention and future partnerships between the public, private and voluntary sector for effective planning action and impact on World heritage conservation. Sustainable development calls for wise management of natural and socio-cultural resources in destination areas. Resources are exploiting by both tourist as well as local host. When this happens, sustainable development is severely threatened: economic wellbeing declines, environmental conditions worsen, social injustice grows, and tourist satisfaction drops (Briassoulis, 2002). Krishnanand and Raman (2019) have highlighted the geographical analysis of geotourism based seasonal economy in Lahaul and Spiti district of Himachal Pradesh. 


\section{STUDY AREA}

Agra city is situated on the bank of River Yamuna in the state of Uttar Pradesh, was preferred by Mugal Emperor Akbar as his capital. Agra, the city of Taj Mahal is widely recognized as one of the most artistically inspiring cities around the world. Taj Mahal, (4.09 million visitor) was the most visited monuments in 2016 for domestic visitors followed by, Qutub Minar, Delhi (2.22 million) and Red Fort, Delhi (2.18 million).

In respect of foreign visitors Taj Mahal (0.396 million) was the most visited monuments, in 2016, followed by Agra Fort, Agra (0.34 million) and Qutub Minar, Delhi (0.33 million), (India tourism statistics report, 2017). There are three UNESCO World Heritage sites: the Taj Mahal, Agra Fort and Fatehpur Sikri. Every year a large number of domestic as well as international tourists visit to this historically important destination. Most of these tourist places are highly significant as they are classified under the UNESCO World Heritage sites. Agra is well connected within the Golden Triangle circuit. It has emerged as the apple of an eye for international and domestic tourists. Delhi - Jaipur and the Uttar Pradesh Heritage Arc is a key factor for generating revenue from the tourism. The city of Agra is perfect example of 'Authenticity'. Robinson (2012), define that any item or activity which is original and genuine. The climate of Agra is tropical in nature with variation in temperature dropping to $3^{\circ} \mathrm{C}$ in winter and rises to $47^{\circ} \mathrm{C}$ in summer. The city is covered with thick fog which makes travel uncomfortable during December and January. Rainy season start from June till September, the annual rainfall of $686 \mathrm{~mm}$ is recorded (Wikipedia). November to February is winter season (Slum Free City Plan of Action Agra). Total population of Agra city is $\mathbf{1 5 . 7 4}$ lakhs with a decadal growth rate of 23.45 percent. The density of city is 11,167 persons per sq.km which is very high when compared to state average of 819 persons per sq.km (SFD Promotion Initiative, Final Report Agra, India, 2016). The city covers an area of $141 \mathrm{sq} . \mathrm{km}$ under Agra Municipal Corporation.

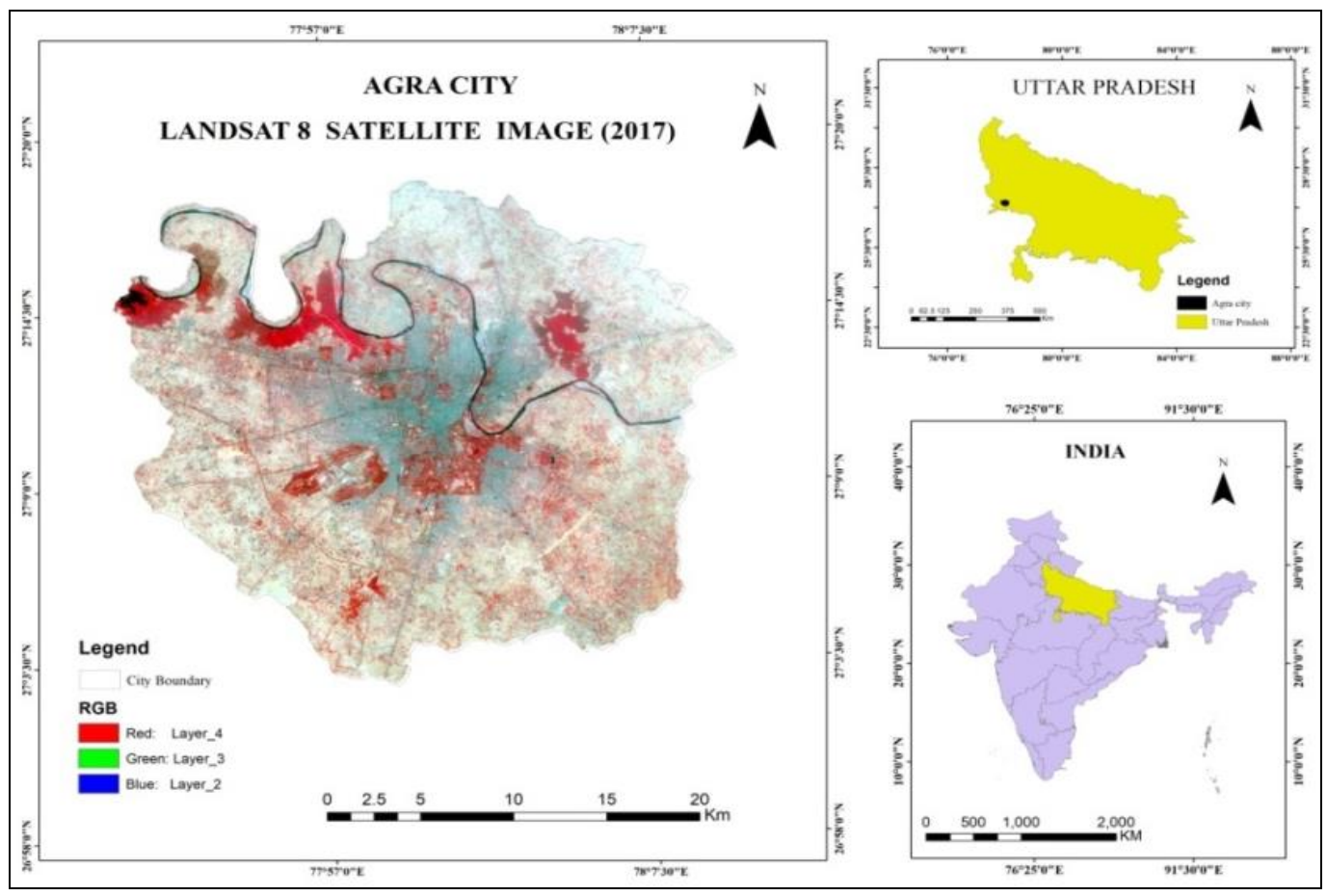

Figure 1. Study Area, 2017 
The Figure 1, shows the map of the study area which was prepared through geospatial technique and Figure 2 shows the different tourist places at Agra city. Agra has its own importance as a commercial city. There are a lot of industrial activities such as Micro, Small and Medium Enterprises (MSME). The major industries are handicraft, marble, leather, carpet, brassware and jeweler crafts. The city has more than five thousand small and medium scale industries which are principally food processing, leather, wood product, electrical and repairing service industries (State Profile of Uttar Pradesh 2014-15). According to slum-free city plan, there are more than 50,000 shops and commercial establishments registered at Agra Nagar Nigam. Small industries include cotton and textile, wood paper products like stationery, leather goods and metal products. Handicrafts include stone carving, inlay work and carpet's making. Shoe making industries are also major source of income and employment. The city has become a major hub for tourist activities which has transformed the whole economy of the city. The major polluting industries have been shifted to other designated industrial areas after the order of Supreme Court (https://lawtimesjournal.in, 2018).

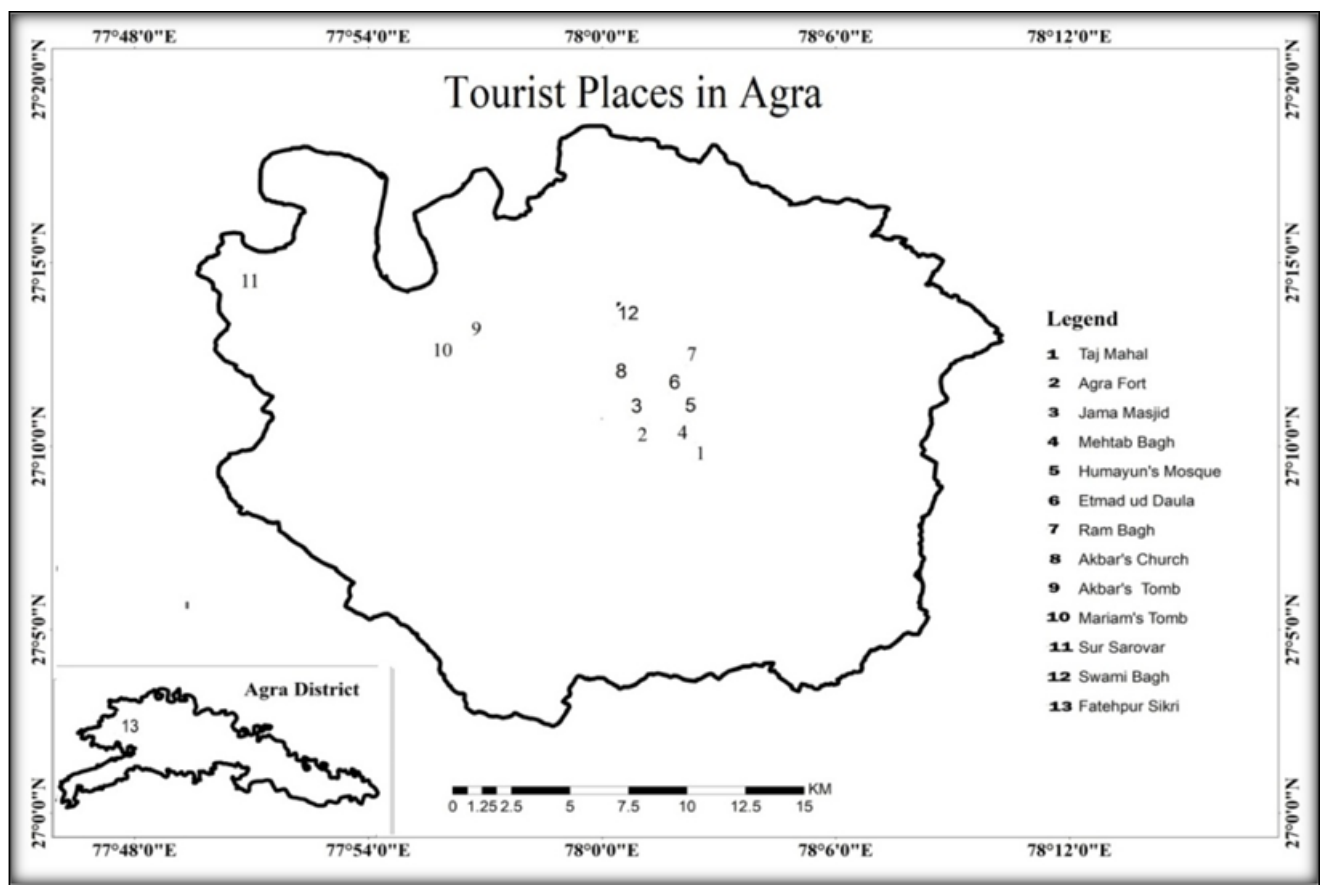

Figure 2. Tourist Places in Agra City, Uttar Pradesh, India

\section{PURPOSE AND METHODOLOGY}

The main objective of the study is to figure out the tourism carrying capacity and sustainable tourism development in Agra. The study is based on primary data collected during the field visits in Agra city and during 2017 and 2018. Primary data sources include the field observation of different monuments of Agra through extensive field survey that includes focused interview and questioners. For analysis of tourism stat us of Agra city, number of field visit was conducted during the various peak tourist periods in 2017 to 2018. This study uses a participant observation approach to examine the status of tourism. These observations base on informal interview and discussion with international and domestic tourist, government stakeholders, local people, hotel staff, 
skilled and unskilled workers. Secondary data of tourist visitors both for international and domestic tourist were collected from the tourism Department of Uttar Pradesh, Ministry of Tourism, India and various reports and of tourism from 2001 to 2018.

\section{RESULTS AND DISCUSSIONS}

Figure 3 and 4 highlight the annual tourists flow from 2004 to 2017 at different monuments in Agra which are under Archeological Survey of India.

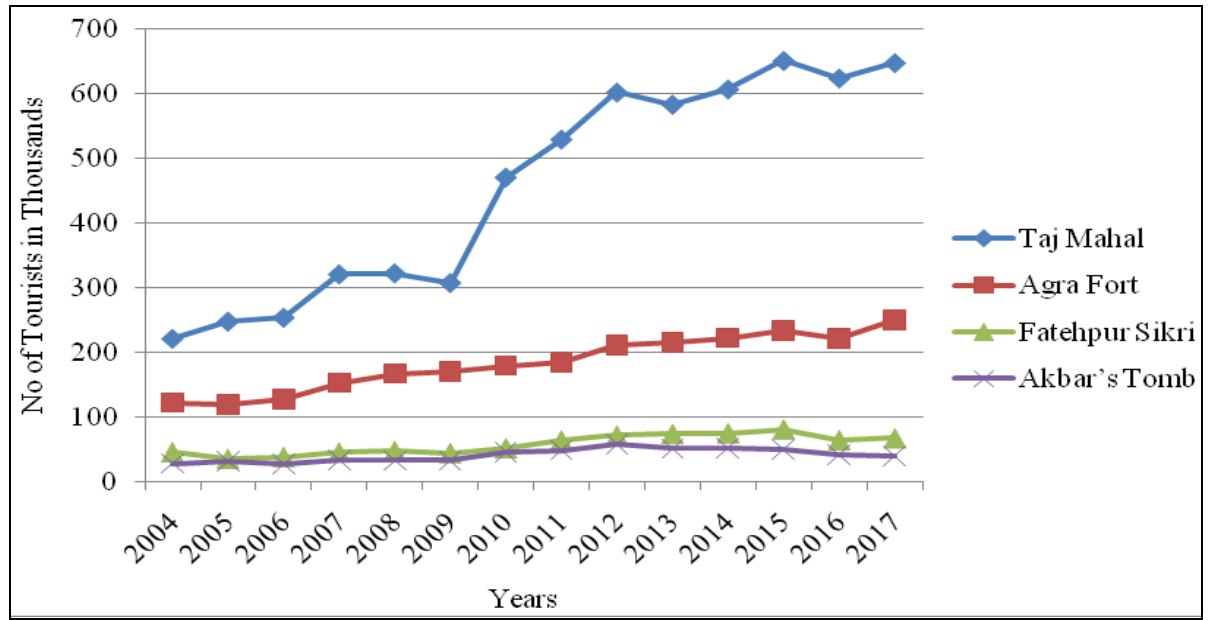

Figure 3. Tourist Flow at Taj Mahal, Agra Fort, Fatehpur Sikri, and Akbar's Tomb (Source: Annual Tourist Visits Statistics, 2004 - 2017, Uttar Pradesh Tourism Department)

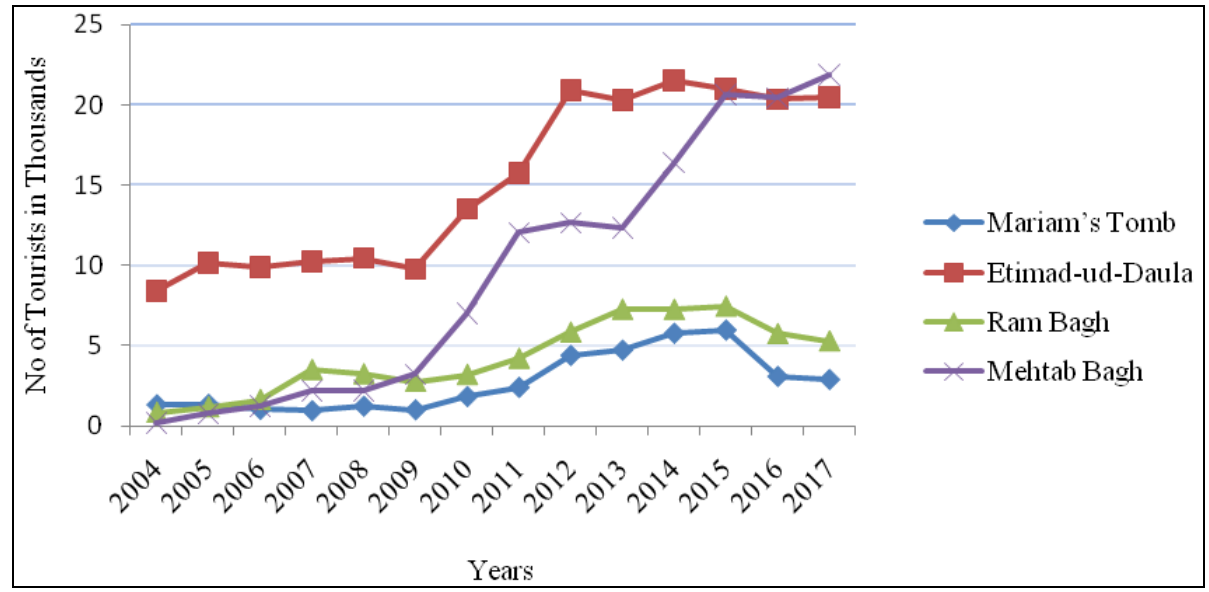

Figure 4 Tourist Flow at Mariam Tomb, Etimad-ud-Daula, Ram Bagh and Mehtab Bagh (Source: Annual Tourist Visits Statistics, 2004 - 2017, Uttar Pradesh Tourism Department)

According to India tourism statistics report, 2017, annual tourist visitors at Taj Mahal in 2017 are 64,802,77 visitors as compared to 22,129,52 visitors in 2004 with high positive growth in tourist flow at Taj Mahal (Table 1). The Red Fort has a positive growth of visitors from 2014 to 2017 and the number of visitors at Red Fort are $12,263,40$ in 2014 and it reached to 25,050,99 visitors in 2017. During 2011 to 2015 there is steady growth in tourist arrival but the year of 2016 was witness of less visitors. 
The annual visitor at Etmad- ul- Daulah in year 2004 is 84,287 visitors which rapidly increasing and reached 20, 488,6 visitor in 2017. But Akbar's Tomb, facing ups and down in number of visitor from 2004 to 2017. The number of annual tourist visitors at Akbar's tomb is high in the year of 2012 but after 2012 there is declining pattern of tourist flow till 2017. The resent trend of visitor flow at Fatehpur Sikri is less as compared to the year of 2015 and shows the declining trend. The main aim of this study is to calculate the tourism carrying capacity and to prepare a sustainable tourism management plan for Agra city. Many of researcher applied carrying capacity as a tool in tourism field (Vishal et al., 2016; Bera et al., 2015). The analysis of tourism sector based on DPSIR model allows one to identify main issues related to tourism activities and to address tourism carrying capacity assessment (Castellani et al., 2007; Kristensen, 2004). The methodology is inspired by DPSIR model framework for sustainable tourism development of Agra city (Figure 5).

Table 1. Annual Tourist Visitors at Monuments (Agra City, India)

(Data Source: Annual Tourist Visits Statistics- 2004 - 2017, Uttar Pradesh Tourism Department)

\begin{tabular}{|c|c|c|c|c|c|c|c|c|}
\hline $\begin{array}{c}\text { Mehtab } \\
\text { Bagh }\end{array}$ & $\begin{array}{c}\text { Ram } \\
\text { Bagh }\end{array}$ & $\begin{array}{c}\text { Etimad-ud- } \\
\text { Daula }\end{array}$ & $\begin{array}{c}\text { Mariam's } \\
\text { Tomb }\end{array}$ & $\begin{array}{c}\text { Akbar's } \\
\text { tomb }\end{array}$ & $\begin{array}{c}\text { Fatehpur } \\
\text { Sikri }\end{array}$ & Agra Fort & Taj Mahal & Year \\
\hline 1937 & 8251 & 84287 & 13239 & 290027 & 467218 & 1226340 & 2212952 & 2004 \\
\hline 7700 & 11695 & 101319 & 13461 & 325890 & 364121 & 1194117 & 2478923 & 2005 \\
\hline 12189 & 16261 & 98811 & 10244 & 281651 & 392015 & 1274717 & 2539471 & 2006 \\
\hline 22149 & 35040 & 102550 & 9473 & 347393 & 461672 & 1534703 & 3210190 & 2007 \\
\hline 22096 & 32406 & 104518 & 12291 & 334305 & 483725 & 1675507 & 3226843 & 2008 \\
\hline 32152 & 27623 & 97651 & 10054 & 335974 & 453988 & 1713006 & 3077114 & 2009 \\
\hline 69965 & 32011 & 135128 & 18292 & 461968 & 525870 & 1799120 & 4709151 & 2010 \\
\hline 120505 & 42127 & 157421 & 24114 & 492885 & 647135 & 1854610 & 5296935 & 2011 \\
\hline 126508 & 58508 & 208936 & 44050 & 585567 & 720984 & 2110591 & 6024816 & 2012 \\
\hline 123210 & 72879 & 202784 & 47365 & 519081 & 744538 & 2158560 & 5835342 & 2013 \\
\hline 163956 & 72781 & 215100 & 57876 & 524135 & 756766 & 2224914 & 6072263 & 2014 \\
\hline 206575 & 74735 & 209916 & 59954 & 500671 & 814781 & 2344260 & 6513543 & 2015 \\
\hline 204352 & 57602 & 203555 & 30924 & 420885 & 651535 & 2215939 & 6242180 & 2016 \\
\hline 218947 & 52991 & 204886 & 29005 & 406391 & 678917 & 2505009 & 6480277 & 2017 \\
\hline
\end{tabular}

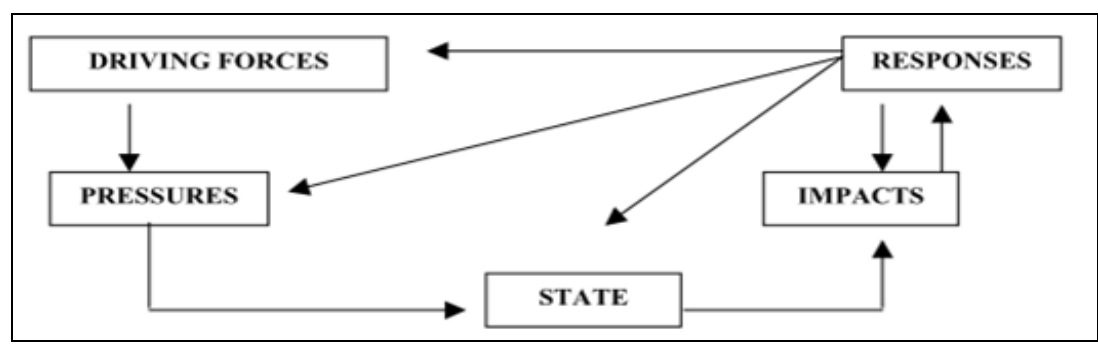

Figure 5. Methodological Flow Chart (Source: Defining, Measuring and Evaluating Carrying capacity in European Tourism Destination, Athens, December 2001)

In this research major issues from the different aspect have been recognized through deep analysis of literature, field survey, discussions with stakeholders and implement through DPSIR model (European Environment Agency, 1999) in this study (Table 2). To calculate the tourism carrying capacity of any tourist destination is a complex task because of its multi-dimensional characteristics. The tourism industry is directly or indirectly linked with the environmental, ecological and socio-cultural aspect of the tourist destination. Here an attempt has been made to calculate physical, accommodation, environmental and economic carrying capacity of Agra city. For calculating the environmental carrying capacity 
there are two components, air quality and biodiversity of Keetham Lake has been examined. The physical carrying capacity of Taj Mahal and accommodation carrying capacity, hospitality density, crowd at heritage place and average revenue generation from the tourism industry is also analyzed. Table 3 summarized the Tourism carrying capacity of Agra city.

Table 2. Application of DPSIR Model of Tourism

\begin{tabular}{|c|l|}
\hline Drivers & $\begin{array}{l}\text { Tourist attendance, Urban traffic, Hospitality structures, Urbanization, Status of } \\
\text { environment }\end{array}$ \\
\hline Pressures & $\begin{array}{l}\text { Air quality, Production of urban solid waste, Use of land, Presence of tourists in } \\
\text { protected areas }\end{array}$ \\
\hline State & $\begin{array}{l}\text { Concentration of pollutant in air, Change of land use, State of local host } \\
\text { community and Tourist satisfaction }\end{array}$ \\
\hline Impacts & $\begin{array}{l}\text { Adverse impact on heritage structures and local host community as well as profile } \\
\text { of tourism industry }\end{array}$ \\
\hline Responses & $\begin{array}{l}\text { Awareness about sustainable tourism activities, Promote eco-friendly transport } \\
\text { and to Promote eco-tourism activities }\end{array}$ \\
\hline
\end{tabular}

Table 3. Tourism Carrying Capacity of Agra City

\begin{tabular}{|c|c|c|c|c|c|c|}
\hline Types & Drivers & Indicator & \multicolumn{3}{|c|}{ State/Classes (Hectares) } & Status \\
\hline \multirow{8}{*}{$\begin{array}{l}\text { Physical } \\
\text { Carrying } \\
\text { Capacity }\end{array}$} & \multirow{6}{*}{ Land use } & \multirow{6}{*}{$\begin{array}{l}\text { City land use / Level } \\
\text { of urbanization } \\
\text { Buffer of Taj Mahal }\end{array}$} & Classes & 1999 & 2017 & Classes \\
\hline & & & Water & 25.11 & 33.66 & Good \\
\hline & & & Green & 159.61 & 166.05 & Good \\
\hline & & & Open space & 124.58 & 70.65 & $\mathrm{Bad}$ \\
\hline & & & \begin{tabular}{|l|l|} 
Settlement \\
\end{tabular} & 149.16 & 191.88 & $\mathrm{Bad}$ \\
\hline & & & Agriculture & 49.77 & 45.99 & $\mathrm{Bad}$ \\
\hline & $\begin{array}{c}\text { PPC of } \\
\text { Taj Mahal }\end{array}$ & $\begin{array}{c}\mathrm{A} * \mathrm{U} / \mathrm{a}{ }^{*} \mathrm{Rf} \\
\text { (Vishal S. et. al. 2016) }\end{array}$ & \multicolumn{3}{|c|}{ Compiled by Author } & $\begin{array}{c}75,111 \\
\text { persons } \\
\text { /day }\end{array}$ \\
\hline & $\begin{array}{l}\text { Crowding in } \\
\text { heritage place }\end{array}$ & $\begin{array}{l}\text { Crowding of natural } \\
\text { sites and streets }\end{array}$ & \multicolumn{3}{|c|}{$\begin{array}{l}\text { Low } \\
\text { Mean } \\
\text { High }\end{array}$} & High \\
\hline $\begin{array}{l}\text { Accommo- } \\
\text { dation } \\
\text { Carrying } \\
\text { Capacity }\end{array}$ & $\begin{array}{c}\text { Number of } \\
\text { Beds in } \\
\text { hotels } \\
\text { in Agra }\end{array}$ & $\begin{array}{c}\text { (TTPM / NM) } \\
\text { TTPM: Total tourist } \\
\text { in peak month } \\
\text { NM: Number of days } \\
\text { In a month }\end{array}$ & \multicolumn{3}{|c|}{$\begin{array}{l}\text { Good } \\
\text { Bad } \\
\text { Poor }\end{array}$} & $\begin{array}{c}31,132 \\
\text { persons } \\
\text { /day }\end{array}$ \\
\hline \multirow{2}{*}{$\begin{array}{l}\text { Environmental } \\
\text { Carrying } \\
\text { Capacity }\end{array}$} & Air Quality & $\begin{array}{l}\text { NO2, SO, PM10, } \\
\text { NOx, Co, O3 }\end{array}$ & \multicolumn{3}{|c|}{ Average of 24 hour } & Moderate \\
\hline & $\begin{array}{l}\text { Biodiversity of } \\
\text { Keetham lake }\end{array}$ & Loss of species & \multicolumn{3}{|c|}{$\begin{array}{l}\text { Judgement through personal } \\
\text { interview/questionnaire }\end{array}$} & Good \\
\hline \multirow{5}{*}{$\begin{array}{l}\text { Economic } \\
\text { Carrying } \\
\text { Capacity }\end{array}$} & \multirow{5}{*}{$\begin{array}{l}\text { Revenue from } \\
\text { tickets }\end{array}$} & \multirow{5}{*}{$\begin{array}{l}\text { Monuments of } \\
\text { Agra circle }\end{array}$} & Year & Tot & Revenue & \multirow{5}{*}{ Increasing } \\
\hline & & & 2014-15 & & 176055 & \\
\hline & & & 2015-16 & & 612150 & \\
\hline & & & 2016-17 & & 80634 & \\
\hline & & & 2017-18 & & 203021 & \\
\hline
\end{tabular}

\section{Tourist Satisfaction Composite Index}

After comprehensive analysis of primary survey and secondary data, it can be concluded that some essential steps are required to improve the conditon of toursit satisfaction in the city. Figure 6 shows the status of satisfication regarding safety, hygiene, environemt, hotel, local transport and sanitary facilities. Most of the respondesnts are not satisfied with the tourist amenities available in the city. Satisfication of tourist is the key 
indicator which shows the present and future perspective of any tourist destination. Figure 6 shows that more than $50 \%$ respondents are unsatisfied with status of hygiene, environement and sanitary facilites which is a matter of serious concern for city that is known for Taj Mahal. These three factors are interlinked with each other.

There is urgent requirement to improve the basic tourist infrastucture in the city to boost tourism. Ticket purchasing at Taj Mahal is very inconvenience activity due to huge number of visitors in peak tourist seasion. Lack of secure transportion facilicites to reach different monuments in the city became a cause of low satisifaction status of Local transportion. Numbre of low budget and unprofessional hotels staff make condition more worst, result decline the tourist satisfaction. All the indecater of satisfacion status shows that high number of percentage of respendent are not satisfied with current satisfaction status of tourism at Agra city.

Figure 6. Satisfaction Status of Tourists in Agra city (Source: Primary Survey, 2017)

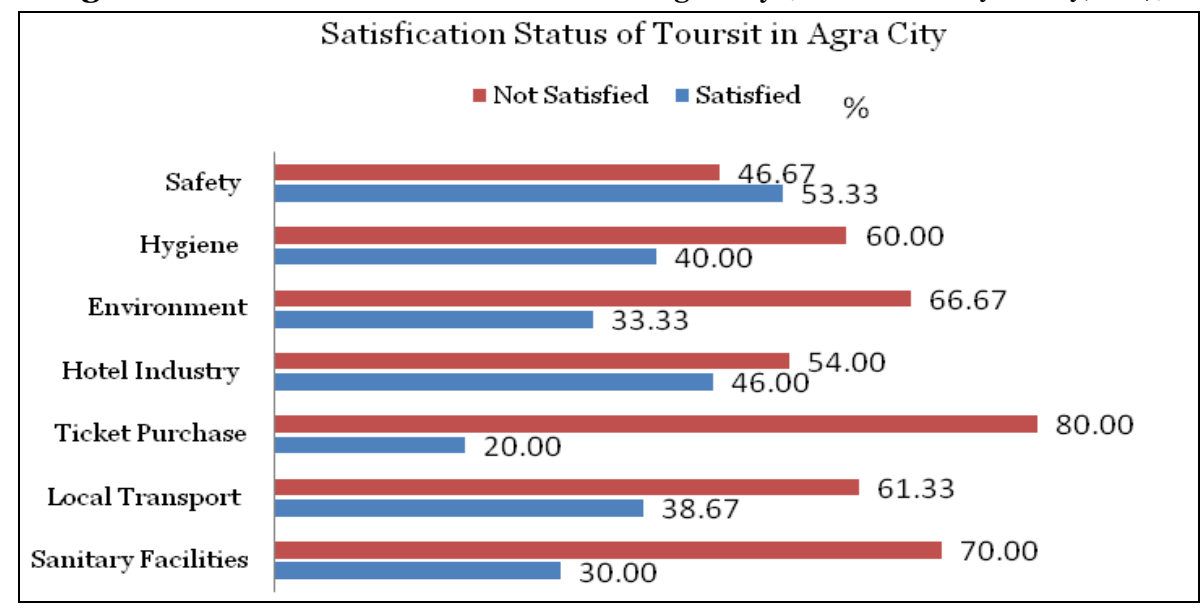

\section{CONCLUSION}

The New Tourism Policy of Uttar Pradesh, 2018 encompasses all required dimensions of sustainable tourism management, therefore it's proper and timely implementation is very essential. Further, developing Agra as a smart city will bring new dimensions in tourism sector in the region. There is urgent need to improve basic urban infrastructure for tourists in Agra. Carrying capacity assessment of tourism in Agra city is really a challenging task. In the context of Agra, the DPSIR model is most suitable for tourism. Various components of DPSIR model are implemented in Agra city and their results are also satisfactory. As we know that the tourism industry is linked with socioeconomic, demographic and ecological parameters of the study area. For assessment of ecological carrying capacity, air quality and biodiversity are taken into consideration.

The air quality in the city is not satisfactory but Keetham Lake is very rich in biodiversity so it has good ecological carrying capacity. If we look at the economic carrying capacity, the revenue from tourism sector is increasing at various monuments of Agra circle. Therefore, economic carrying capacity of town is increasing.

The sustainable and eco-tourism development is possible by taking various sociocultural, environmental and economic dimensions into consideration. Various tourism laws and policies have been formulated from time to time but their implementation part is lacking at various levels. Proposed activities like development of Yamuna river front and proposed bridge between MehtabBagh and Taj Mahal, redevelopment of Keetham 
lake and Sur Sarovar bird sanctuary and development of rural tourism is required for transformation of tourism industry in the region and its surroundings. Master Plan 2021 and City Development Plan (CDP) 2006 both have integrated and holistic planning parameters for various sectors including tourism but there implementation is a real challenge. The Public Private Partnership (PPP) model can help in implementing the various amenities through civic bodies like Agra Nagar Nigam etc. Agra as a smart city can be made a smart tourist destination with the help of latest technology. Recently several initiatives have been taken by the central government to promote tourism in the country, probably; it shall have positive impact in Agra city as well. These include PRASAD, creation of world class tourism infrastructure, and growth of tourist footfalls, multilingual tourist helpline, skill development and Adarsh Smarak etc.

\section{Acknowledgement}

The authors are very grateful to Department of Geography, Shaheed Bhagat Singh College, and University of Delhi for providing institutional support during research period 2017-2018.

\section{REFERENCES}

Adriansyah, D., Busu, I., Eva, H., \& Muqtada, M. (2015). Geoheritage as the basis for geotourism development: A case study in Jeli District, Kelantan, Malaysia, GeoJournal of Tourism and Geosites, Year VIII, no. 1, Vol. 15, pp 25-43.

Bera, S., Dipanjan D., M., \& Ashis, K., P. (2015). Estimation of tourism carrying capacity for Neil Island, South Andaman, India, Journal of Coastal Sciences, Vol. 2, No. 2 pp 46-53.

Briassoulis, H. (2002). Sustainable tourism and the question of the commons: Annals of tourism research, Great Britain, Vol. 29, no. 4, pp 1065-1085.

Castellani, V., Sala. S., \& Pitea, D. (2007). A New method of tourism carrying capacity assessment, University of Milano Bicocca, department of environmental science, Italy, ecosystems and sustainable development, Vol. 106, doi:10.2495/ECO0703401.

Dowling, R.K. (2008). The Emergence of Geotourism and Geoparks. Journal of Tourism, 9(2), 227-236.

Dowling, R.K. \& Newsome, D. (2006). Geotourism. Elsevier, Oxford, (eds.).

Drost, Anne. (1996). Developing sustainable tourism for world heritage sites. Annals of tourism research, Elsevier, 23(2), pp.3-16.

Krishnanand \& Raman, V., A., V., (2019). Geographical analysis of geotourism based seasonal economy in Lahaul and Spiti district of Himachal Pradesh, GeoJournal of Tourism and Geosites Year XII, vol. 24, no. 1, 2019, p.118-132 ISSN 2065-0817.

Kristensen, P. (2004). The DPSIR Framework, National Environmental Research Institute, Denmark. Paper presented at Nairobi, Kenya.

Nimesh, S., K. (2013). New approaches to study tourism: A case study. Weekly science research journal, Vol. 1, Issue-7, pp. 2321-7871

Robinson, P. (2012). Tourism: The key concepts, Routledge publication, United Kingdom.

Vishal, S., Vardhan, B., H., Amruta, A., Swapnil, R., \& Rao, P., S. (2016). A case study of Taj Mahal's visitor satisfaction and carrying capacity. Journal of hospitality management and tourism, Vol. 7(4), pp 43-49.

*** Defining, measuring and evaluating carrying capacity in European tourism destination, (2001). B43040/2000/294577/MAR/D2, final report, Athens.

*** European Environment Agency (1999). EEA, DK-1050, annual report, Copenhagen, Denmark.

*** India tourism statistics report, (2017), Government of India, New Delhi.

*** New tourism policy of Uttar Pradesh, (2018). Department of Tourism, Government of Uttar Pradesh, Lucknow.

*** SFD promotion initiative, Final report Agra, India, (2016), Centre for Science and Environment (CSE). New Delhi.

*** Slum free city plan of action, Agra, regional centre for urban and environmental studies, sponsored by ministry of urban Development, government of India, Osmania University, Hyderabad.

*** State profile of Uttar Pradesh, (2014 - 2015), MSME development institute, Oct. 2015.

https://lawtimesjournal.in/m-c-mehta-v-union-of-india-1986-taj-trapezium-case-case-summary.

www.uptourism.gov.in/pages/top/about-up-tourism/year-wise-tourist-statistics.

https://en.wikipedia.org/wiki/Agra.

Submitted:

05.02.2019
Revised:

03.05.2019
Accepted and published online 22.05.2019 